\title{
FK506 Augments Activation-induced Programmed Cell Death of T Lymphocytes In Vivo
}

Kiyoshi Migita, Katsumi Eguchi, Yojiro Kawabe, Toshiaki Tsukada, Akinari Mizokami, and Shigenobu Nagataki The First Department of Internal Medicine, Nagasaki University School of Medicine, Nagasaki 852, Japan

\begin{abstract}
FK506 is an immunosuppressive drug that inhibits $\mathbf{T}$ cell receptor-mediated signal transduction. This drug can induce immunological tolerance in allograft recipients. In this study, we investigated the in vivo effects of FK506 on T cell receptor-mediated apoptosis induction. Injection of anti$\mathrm{CD3}$ antibody $(\mathrm{Ab})$ in mice resulted in the elimination of $\mathrm{CD4}^{+} \mathrm{CD8}^{+}$thymocytes by DNA fragmentation. FK506 treatment significantly augmented thymic apoptosis induced by in vivo anti-CD3 Ab administration. Increased thymic apoptosis resulted in the disappearance of $\mathrm{CD4}^{+} \mathrm{CD8}^{+}$thymocytes after anti-CD3 Ab/FK506 treatment. DNA fragmentation triggered by FK506 was induced exclusively in antigen-stimulated $T$ cells, since enhanced DNA fragmentation induced by in vivo staphylococcal enterotoxin B (SEB) injection was confirmed in SEB-reactive $\mathrm{VBr}^{+}$thymocytes but not in SEB-nonreactive ${\mathrm{V} \beta 6^{+}}^{+}$thymocytes. In addition to thymocytes, mature peripheral $T$ cells also die by activationinduced programmed cell death. A similar effect of FK506 on activation-induced programmed cell death was observed in SEB-activated peripheral spleen $T$ cells. In contrast, cyclosporin A treatment did not enhance activation-induced programmed cell death of thymocytes and peripheral $T$ cells. Apoptosis is required for the generation and maintenance of self-tolerance in the immune system. Our findings suggest that FK506-triggered apoptosis after elimination of antigen-activated $T$ cells may represent a potential mechanism of the immunological tolerance achieved by FK506 treatment. (J. Clin. Invest. 1995. 96:727-732.) Key words: FK506 $\bullet$ apoptosis $\bullet$ superantigen $\cdot$ immunological tolerance - $\mathbf{T}$ cells
\end{abstract}

\section{Introduction}

FK506, a macrolide lactone isolated from Streptomyces tsukbaenesis, is a potent immunosuppressive agent $(1,2)$. It is used clinically in organ transplantation, such as liver, kidney, and pancreas $(3,4)$. It is well accepted that FK506 acts by strongly inhibiting lymphokine production by $\mathrm{T}$ cells $(5-7)$. However,

Address correspondence to Kiyoshi Migita, MD, The First Department of Internal Medicine, Nagasaki University School of Medicine, 1-7-1 Sakamoto, Nagasaki 852, Japan. Phone: 958-49-7266; FAX: 958-497270.

Received for publication 14 December 1994 and accepted in revised form 3 May 1995.

J. Clin. Invest.

(C) The American Society for Clinical Investigation, Inc. 0021-9738/95/08/0727/06\$2.00

Volume 96, August 1995, 727-732 little is known about the in vivo immunosuppressive effects of FK506. Furthermore, in vivo FK506 studies have assessed its pharmacological effects on allograft survival but have not addressed its in vivo effect on $T$ cell activation and immunosuppression. This study was prompted by several previous studies reporting the induction of immunological tolerance by FK506. We hypothesized that FK506 can establish immunological tolerance in vivo by affecting $\mathrm{T}$ cell apoptosis.

The establishment of $\mathrm{T}$ cell tolerance is known to occur primarily in the thymus gland, where autoreactive $\mathrm{T}$ cells are deleted by apoptosis $(8,9)$. However, similar to thymocytes, peripheral $\mathrm{T}$ cells surviving thymic selection may undergo apoptosis by antigen-mediated stimulation $(10,11)$. Apoptosis, also termed programmed cell death, is a signal-dependent suicide form of cell death and is required for the generation and maintenance of self-tolerance $(12,13)$. Several stimuli induce apoptosis, including stimulation of $\mathrm{T}$ and $\mathrm{B}$ cells via antigen receptors, irradiation, and exposures to cytokines, such as TNF and TGF- $\beta$ (14-17).

In the present series of experiments, we examined the in vivo effect of FK506 on the T cell activation-induced programmed cell death triggered by $\mathrm{T}$ cell receptor-mediated stimulation. Our results showed that in vivo FK506 treatment eliminated antigen-stimulated $\mathrm{T}$ cells through DNA fragmentation. Alloantigen-stimulated cytolytic $\mathrm{T}$ cells contribute to the rejection of transplanted allografts and graft-versus-host disease (GVHD). ${ }^{1}$ The elimination of these activated cytolytic $\mathrm{T}$ cells may silence these phenomena. Our results suggest that FK506induced apoptosis of antigen-stimulated $\mathrm{T}$ cells may represent one of the mechanisms of immunological tolerance.

\section{Methods}

\section{Antibodies and reagents}

Murine anti-CD3 specific monoclonal antibody ( $\mathrm{mAb}$ ) producing B cell hybridoma $2 \mathrm{C} 11$ (18) was kindly provided by Dr. J. A. Bluestone (University of Chicago, Chicago, IL). Monoclonal anti-CD3 Ab was purified in our laboratory using Protein G-Sepharose column (Pharmacia Biotech, Uppsala, Sweden) from culture supernatant. Anti-V $\beta 8.1$, 2, 3 specific monoclonal antibody producing $B$ cell hybridoma F23.1 (19) was kindly provided by Dr. M. J. Bevan (Research Institute of Scripps Clinic, La Jolla, CA). The antibody was purified and biotinylated in our laboratory. Phycoerythrin (PE) -anti-CD4 and FITC-antiCD8 Ab were purchased from Becton Dickinson (Mountain View, CA). FK506 and cyclosporin A (CsA) were kindly provided by Fujisawa Pharmaceuticals (Osaka, Japan) and Sandoz (Tokyo, Japan). All other reagents were purchased from Sigma Immunochemicals (St. Louis, MO).

1. Abbreviations used in this paper: CsA, cyclosporin A; GVHD, graft-versus-host disease; PE, phycoerythrin; SEB, staphylococcal enterotoxin B 
Mice

Balb/c mice (3-4 wk old) were obtained from Japan SLC, Inc. (Hamamatsu, Japan). Mice were injected intraperitoneally with anti-CD3 Ab (30 $\mu \mathrm{g}$ ), staphylococcal enterotoxin B (SEB, $50 \mu \mathrm{g}$; Sigma Immunochemicals), FK506 (2 mg/kg), or CsA (50 mg/kg).

\section{Cell preparation}

Spleen $T$ cells. Spleen single cell suspensions were isolated and treated with Tris-buffered $0.16 \mathrm{M}$ ammonium chloride to lyse red blood cells. $\mathrm{T}$ cells were enriched by depletion of surface Ig-positive cells on goat anti-mouse IgG $(100 \mu \mathrm{g} / \mathrm{ml})$-coated Petri dishes. Nonadherent cells were further incubated with anti-rat IgG-coated $\mathrm{Fe}_{2} \mathrm{O}_{3}$ cross-reactive to mouse IgG (Dynabeads M450; DYNAL, Oslo, Norway), and then sorted by magnetically activated cell sorter (MACS; Miltenyi Biotec $\mathrm{GmbH}$, Meilzfeld, Germany). This process resulted in a negatively selected CD3-positive $\mathrm{T}$ cell population $\left(\sim 95 \%\right.$ of $\mathrm{CD}^{+}$cells $)$. This population will be referred to as spleen $\mathrm{T}$ cells.

$V \beta 8$ and $V \beta 6$ positive thymocytes. Thymus glands were dissected from mice, and thymocytes were incubated for $30 \mathrm{~min}$ with biotinylated anti-V $\beta 8$ or $\mathrm{V} \beta 6 \mathrm{Ab}$ at $10 \mu \mathrm{g} \mathrm{Ab}$ per $5 \times 10^{7}$ cells $/ \mathrm{ml}$. Cells were washed and mixed with streptavidin- $\mathrm{Fe}_{2} \mathrm{O}_{3}$ (Dynabeads M280; DYNAL) at $10 \mu 1 / 10^{5}$ cells for $30 \mathrm{~min}$ on ice. Magnetically coated cells were isolated by MACS.

\section{DNA fragmentation assay}

Thymocytes were washed with cold phosphate-buffered saline solution (PBS). Fresh or cultured thymocytes were collected by centrifugation at $200 \mathrm{~g}$ for $10 \mathrm{~min}$. The pellets were lysed with $1.0 \mathrm{ml}$ of lysis buffer ( $10 \mathrm{mM}$ Tris, $\mathrm{pH} 7.5,1.0 \mathrm{mM}$ EDTA, $0.2 \%$ Triton X-100). The lysate was centrifuged at $13,000 \mathrm{~g}$ for $10 \mathrm{~min}$, and the supernatant containing fragmented DNA was collected. DNA was precipitated overnight at $-20^{\circ} \mathrm{C}$ in $50 \%$ isopropanol and $0.5 \mathrm{M} \mathrm{NaCl}$. The precipitate was collected after centrifugation at $13,000 \mathrm{~g}$, air-dried, and suspended in 10 $\mathrm{mM}$ Tris, $1.0 \mathrm{mM}$ EDTA, $\mathrm{pH}$ 7.5. A loading buffer containing $15 \mathrm{mM}$ EDTA, $2 \%$ SDS, $50 \%$ glycerol, and $0.05 \%$ bromophenol blue was added at $1: 5(\mathrm{vol} / \mathrm{vol})$. Samples were heated at $65^{\circ} \mathrm{C}$ for $10 \mathrm{~min}$ and electrophoresed in a $1 \%$ agarose gel. Electrophoresis was carried out in 80 $\mathrm{mM}$ Tris-phosphate, $2 \mathrm{mM}$ EDTA, pH 8.0. Gels were later stained with $0.5 \mu \mathrm{g} / \mathrm{ml}$ ethidium bromide, and visualization of DNA was accomplished using ultraviolet light.

\section{FACS ${ }^{\circledR}$ analysis}

Thymocytes from each thymus gland were counted and stained with FITC-anti-CD8 and PE-anti-CD4 monoclonal antibodies for $30 \mathrm{~min}$ on ice. Spleen single cell suspensions were treated with Tris-buffered $0.16 \mathrm{M}$ ammonium chloride to lyse red blood cells. Spleen cells were treated with biotin-conjugated anti- $\mathrm{V} \beta 8$ or anti- $\mathrm{V} \beta 6$ monoclonal antibody for $30 \mathrm{~min}$ on ice. The washed cells were incubated with FITCavidin and PE-anti-CD4 antibody. Stained cells were analyzed using EPICS PROFILE (Coulter Corp., Hialeah, FL) flowcytometer. In a few experiments, apoptosis was quantified by flowcytometric determination of the proportion of cells with hypodiploid DNA using the method of Perandones et al. (20). Spleen T cells were resuspended in $1.0 \mathrm{ml}$ of hypotonic PI solution ( $3.4 \mathrm{mM}$ sodium citrate, $50 \mu \mathrm{g} / \mathrm{ml}$ propidium iodide, $0.1 \%$ Triton X-100, $1.0 \mathrm{mM}$ Tris, $0.1 \mathrm{mM}$ EDTA) and stored in darkness on ice until they were analyzed by FACS ${ }^{\circledR}$. Apoptotic nuclei were distinguished by their hypodiploid DNA content compared with the diploid DNA content of normal nuclei.

\section{Results}

FK506 augmented anti-CD3 Ab-induced thymic apoptosis. It is known that in vivo administration of anti-CD3 Ab causes the deletion of immature thymocytes by apoptosis (21). Using this system, we examined the in vivo effect of FK506 and CsA on thymocyte activation-induced programmed cell death. To detect
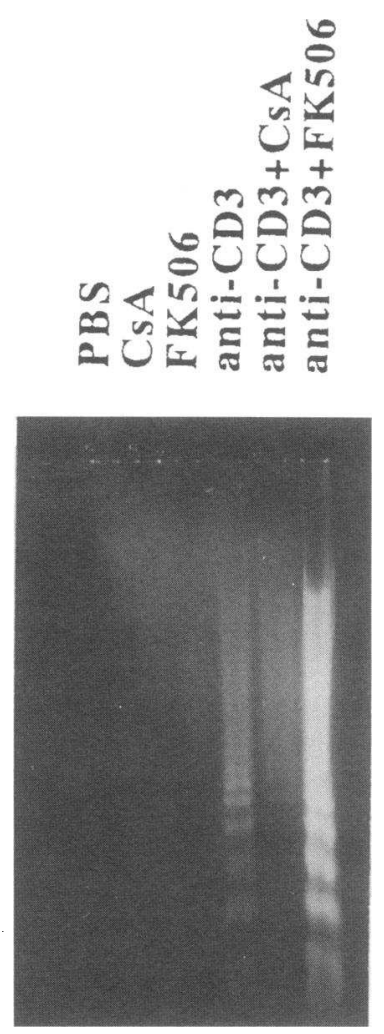

Figure 1. A representative example of three similar experiments showing FK506 augmentation of thymocyte DNA fragmentation induced by anti$\mathrm{CD} 3 \mathrm{Ab}$ in vivo. Balb/c mice were injected intraperitoneally with PBS, CsA ( $50 \mathrm{mg} / \mathrm{kg}$ ), FK506 (2 mg/kg), anti-CD3 $\mathrm{Ab}(30 \mu \mathrm{g})$, anti-CD3 $\mathrm{Ab}$ and CsA, or anti-CD3 Ab and FK506. Thymus glands were removed $16 \mathrm{~h}$ after injection, thymocytes $\left(2 \times 10^{6} \%\right.$ each sample) were lysed, and fragmented DNA in the supernatant was extracted and separated in $1 \%$ agarose gel electrophoresis.

DNA fragmentation, freshly prepared mice thymocytes were analyzed by agarose gel electrophoresis $16 \mathrm{~h}$ after anti-CD3 Ab, CsA, or FK506 injection. As shown in Fig. 1, DNA fragmentation was not observed in thymocytes of PBS, CsA (50 $\mathrm{mg} / \mathrm{kg}$ ), or FK506 (2 mg/kg) injected mice. Fragmentation of thymocyte DNA occurred $16 \mathrm{~h}$ after anti-CD3 Ab $(30 \mu \mathrm{g})$ injection. A simultaneous injection of anti-CD3 Ab and FK506 was followed $16 \mathrm{~h}$ later by examination of thymocyte DNA fragmentation. FK506 significantly enhanced thymic DNA fragmentation induced by anti-CD3 Ab stimulation. In contrast, in vivo CsA treatment partially inhibited anti-CD3 $\mathrm{Ab}$-induced thymic apoptosis (Fig. 1).

We also analyzed the surface expression of CD4 and CD8 molecules on thymocytes after anti-CD3 Ab, CsA, or FK506 injection (Fig. 2). In vivo anti-CD3 $\mathrm{Ab}$ administration reduced $\mathrm{CD} 4{ }^{+} \mathrm{CD} 8{ }^{+}$thymocytes. Treatment with anti-CD3 Ab and FK506 caused a more marked deletion of $\mathrm{CD}^{+}{ }^{+} \mathrm{CD} 8{ }^{+}$immature thymocytes compared with that observed with anti-CD3 Ab alone. But in vivo CsA treatment did not enhance the deletion of $\mathrm{CD} 4{ }^{+} \mathrm{CD} 8{ }^{+}$thymocytes induced by anti-CD3 Ab.

FK506 augmented SEB-induced thymic apoptosis in vivo. Administration of SEB, a bacterial superantigen, is known to induce the antigen-specific thymocyte elimination by apoptosis (22). We investigated the effect of FK506 on SEB-induced thymic apoptosis. Analysis of DNA extracted from SEB (50 $\mu \mathrm{g})$-injected mice thymocytes was performed using agarose gel electrophoresis. As shown in Fig. 3 A, some DNA fragmentation was observed in SEB-primed thymocytes $16 \mathrm{~h}$ after injection. However, DNA fragmentation was better enhanced in SEBFK506-primed mice thymocytes. To determine whether the latter occurred selectively in SEB-activated thymocytes, we analyzed the DNA of SEB-reactive $\mathrm{V} \beta 8$-positive thymocytes. 

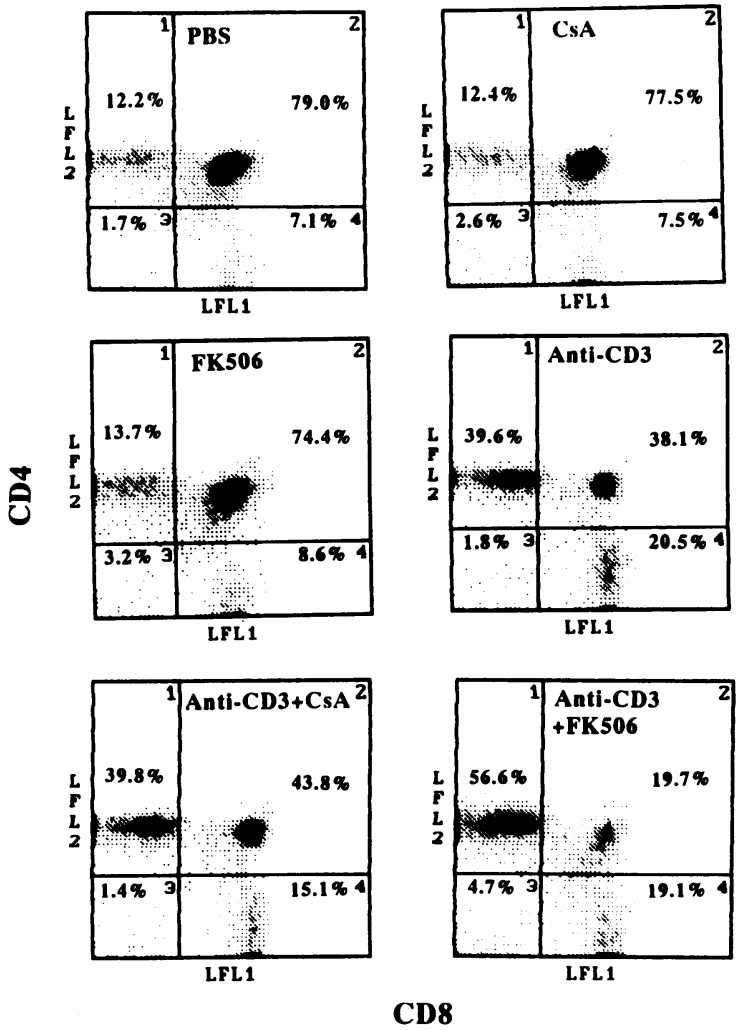

Figure 2. FK506 enhanced anti-CD3 Ab-induced deletion of $\mathrm{CD} 4{ }^{+} \mathrm{CD}^{+}$thymocytes in vivo. Balb/c mice were intraperitoneally injected with PBS, CsA, FK506, anti-CD3 Ab, anti-CD3 Ab and CsA, or anti-CD3 Ab and FK506. After $24 \mathrm{~h}$, thymus glands were removed, and thymocytes were stained with FITC-anti-CD8 and PE-anti-CD4 $\mathrm{mAb}$ and analyzed by flowcytometer. Cell numbers per thymus of triplicate treated mice were also determined. PBS, 108.3 \pm 11.8 ; CsA, 102.4 \pm 13.4 ; FK506, 98.7 \pm 21.0 ; anti-CD3 Ab, 40.5 \pm 4.2 ; anti-CD3 $\mathrm{Ab}+\mathrm{CsA}, 44.5 \pm 5.5$; anti-CD3 Ab+FK506, 35.5 \pm 3.8 . (cells/gland, in millions ).

$\mathrm{V} \beta 8$-positive thymocytes were purified by magnetic beads, and fragmented DNA was extracted and electrophoresed. In vivo FK506 treatment augmented DNA fragmentation in SEB-reactive $\mathrm{V} \beta 8$-positive thymocytes. However, no DNA fragmentation of SEB-FK506-primed mice thymocytes was observed in control V $\beta 6$-positive thymocytes (Fig. $3 B$ ).

FK506 augmented peripheral T cell apoptosis induced by in vivo SEB administration. SEB $(50 \mu \mathrm{g})$ was injected intravenously into mice that were killed $3 \mathrm{~d}$ later. As previously reported, after $2 \mathrm{~h}$ of in vitro culture, the DNA of SEB-primed spleen $T$ cells had a ladder-like pattern, characteristic of apoptosis (10). On day 3 after SEB administration, FK506 (2 $\mathrm{mg} / \mathrm{kg}$ ), CsA ( $50 \mathrm{mg} / \mathrm{kg}$ ), or PBS was injected into mice that were killed $6 \mathrm{~h}$ later. The spleen T cells were cultured for $2 \mathrm{~h}$ in vitro, and fragmented DNA was extracted and electrophoresed. Increased DNA fragmentation was detected in FK506-treated spleen T cells compared with PBS-treated spleen T cells. But the DNA fragmentation of CsA-treated spleen $T$ cells was not changed compared with that of PBS-treated spleen T cells (Fig. $4 A$ ). Furthermore, DNA fragmentation was observed in freshly isolated SEB-primed spleen T cells treated with FK506 for $6 \mathrm{~h}$
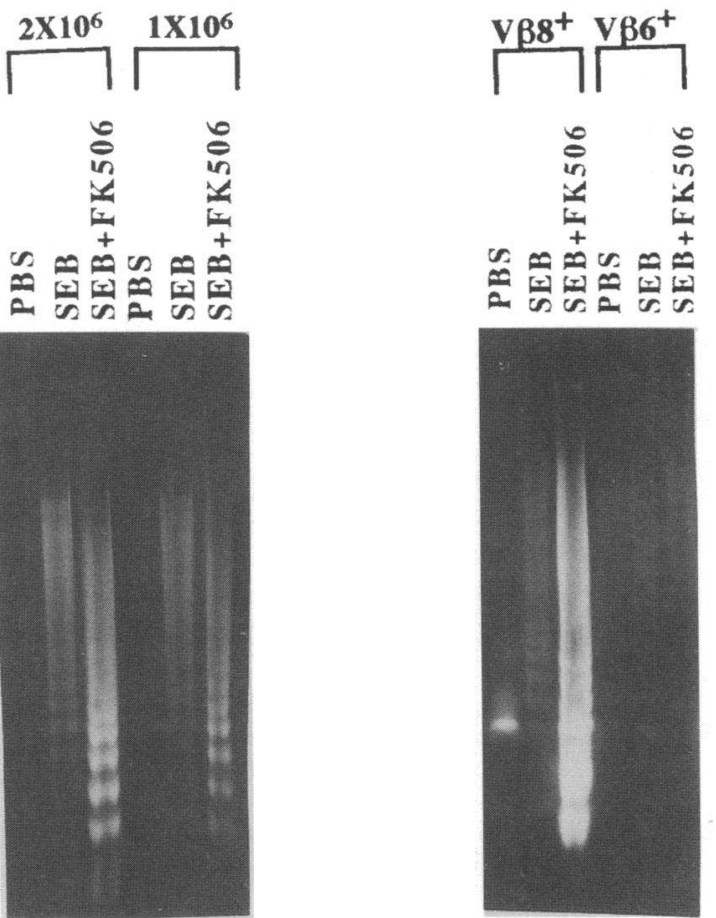

Figure 3. A representative example of three similar experiments showing FK506 augmented thymocyte DNA fragmentation induced by SEB in vivo. Balb/c mice were injected with PBS, SEB $(50 \mu \mathrm{g})$, or SEB and FK506 $(2 \mathrm{mg} / \mathrm{kg})$. Thymus glands were removed $16 \mathrm{~h}$ after injection, thymocytes $\left(2 \times 10^{6}\right.$ or $\left.1 \times 10^{6}\right)$ were lysed, and fragmented DNA in supernatant was extracted and separated in $1 \%$ agarose gel electrophoresis $(A)$. Balb/c mice were intraperitoneally injected with PBS, SEB $(50 \mu \mathrm{g})$, or SEB and FK506 $(2 \mathrm{mg} / \mathrm{ml})$. Thymus glands were removed $16 \mathrm{~h}$ after injection, and $\mathrm{V} \beta 8$ - or $\mathrm{V} \beta 6$-positive thymocytes were purified by MACS. Thymocytes $\left(1 \times 10^{6}\right)$ were lysed, and fragmented DNA in the supernatant was extracted and separated by $1 \%$ agarose gel electrophoresis $(B)$.

in vivo (Fig. $4 B$ ). We measured the percentage of $\mathrm{V} \beta 8+\mathrm{T}$ cells, the population supposed to have undergone apoptosis, between FK506- or PBS-treated mice before the start of the in vitro culture. However, there was no difference in the percentage of SEB-primed $\mathrm{V} \beta 8^{+} \mathrm{T}$ cells on day 3 between both mice (data not shown).

We also measured the percentage of the apoptotic $\mathrm{T}$ cells with hypodiploid DNA content by FACS ${ }^{\circledR}$ analysis. Flowcytometric analysis showed an increase in SEB-primed $T$ cells with hypodiploid DNA in FK506-treated mice compared with control mice (data not shown).

Profound reduction of $\mathrm{VB8^{+ }} \mathrm{CD}^{+} \mathrm{T}$ cells in SEB-FK506treated mice. In vivo administration of SEB induced a partial elimination of SEB-reactive $\mathrm{V} \beta 8^{+} \mathrm{T}$ cells. $3 \mathrm{~d}$ after injection of SEB, mice were injected with FK506, CsA, or PBS, and analysis of the percentage of $\mathrm{V} \beta 8^{+} \mathrm{CD}^{+}$or $\mathrm{V} \beta 6^{+} \mathrm{CD} 4^{+}$in spleen $\mathrm{T}$ cells was performed on day 7 . As expected, enhanced deletion of $\mathrm{V} \beta 8^{+} \mathrm{CD} 4{ }^{+}$was observed in FK506-treated murine 

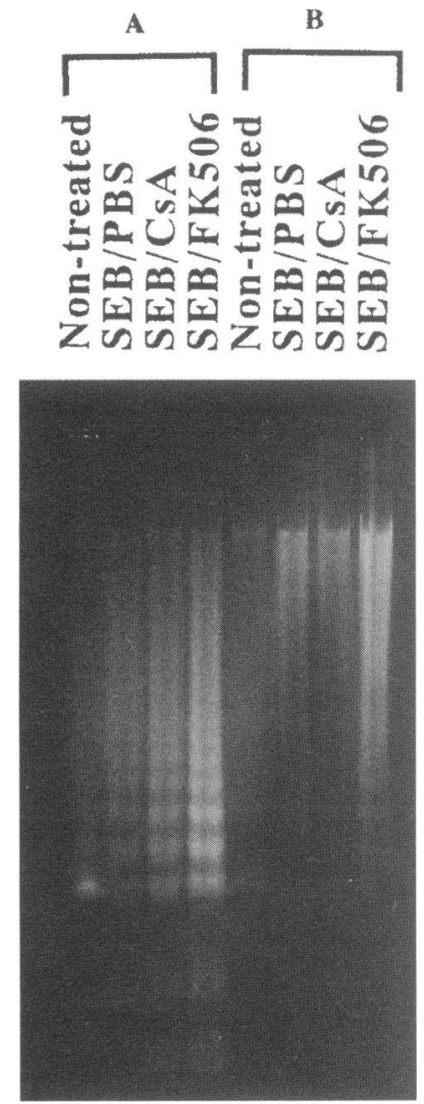

Figure 4. A representative example of three similar experiments showing FK506 augmented DNA fragmentation in spleen $T$ cells induced by SEB in vivo. Balb/c mice were injected intraperitoneally with SEB $(50 \mu \mathrm{g})$ or PBS (Non-treated). Mice were injected intraperitoneally with CsA (50 mg/kg), FK506 ( $2 \mathrm{mg} / \mathrm{kg}$ ), or PBS $72 \mathrm{~h}$ after SEB injection. Mice were killed $6 \mathrm{~h}$ after FK506, CsA, or PBS injection, spleen T cells were isolated, and some $T$ cells were cultured. Cultured $\mathrm{T}$ cells $\left(2 \times 10^{6}, A\right)$ or fresh $\mathrm{T}$ cells $\left(2 \times 10^{7}, B\right)$ were lysed, and fragmented DNA in the supernatant was extracted and separated by $1 \%$ agarose gel electrophoresis.

spleen $\mathrm{T}$ cells (Fig. $5 \mathrm{~A}$ ). However, the percentage of control $\mathrm{V} \beta 6^{+} \mathrm{CD}^{+} \mathrm{T}$ cells in FK506-treated was not different from that of untreated mice (Fig. $5 B$ ). We measured the percentage
Table I. FK506 Enhances Elimination of $\mathrm{CD}^{+} \mathrm{V} \beta 8^{+} \mathrm{T}$ Cells in SEB-treated Mice*

\begin{tabular}{lll}
\hline & \multicolumn{2}{c}{ Percentage of positive cells } \\
\cline { 2 - 3 } Treatment $^{\ddagger}$ & $\mathrm{CD}^{+} \mathrm{V} \beta 8^{+}$ & $\mathrm{CD}^{+} \mathrm{V} \beta 6^{+}$ \\
\hline PBS & $25.7 \pm 2.1$ & $10.3 \pm 1.0$ \\
PBS/FK506 & $26.2 \pm 1.8$ & $10.1 \pm 0.6$ \\
SEB & $20.6 \pm 2.7$ & $10.2 \pm 1.3$ \\
SEB/FK506 & $14.5 \pm 1.9$ & $10.4 \pm 1.4$ \\
\hline
\end{tabular}

* Spleen cell suspensions were prepared from four groups of treated mice $7 \mathrm{~d}$ after PBS or SEB injection and analyzed for expression for CD4 and V $\beta$ by flowcytometer. FK506 was injected $3 \mathrm{~d}$ after PBS or SEB injection. Data represent the average of triplicate samples. ${ }^{\ddagger}$ There was little difference of total $\mathrm{T}$ cell numbers in these four groups of treated mice. ${ }^{\S} \mathrm{V} \beta 8^{+}$or $\mathrm{V} \beta 6^{+}$cells were measured and their proportions in $\mathrm{CD}^{+} \mathrm{T}$ cells are calculated.

of $\mathrm{CD} 4^{+} \mathrm{V} \beta 8^{+} \mathrm{T}$ cells using several PBS- or SEB-treated mice and confirmed that this enhancement on $\mathrm{CD}^{+} \mathrm{V} \beta 8^{+} \mathrm{T}$ cell deletion was consistently induced by in vivo FK506 treatment (Table I).

In vivo injection of SEB also induces a state of anergy in peripheral $\mathrm{T}$ cells, when $\mathrm{T}$ cells are challenged with SEB in vitro (23). However, in vivo FK506 treatment failed to influence SEB-induced anergy state (data not shown).

\section{Discussion}

FK506 is a powerful immunosuppressant drug used clinically to prevent allograft rejection (1-4). In vitro studies have dem-
A

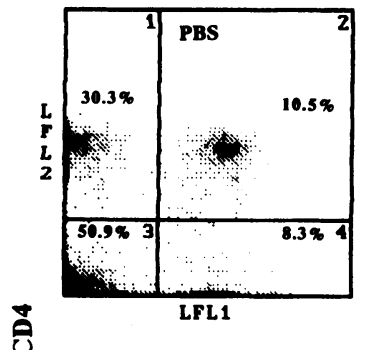

ชิ

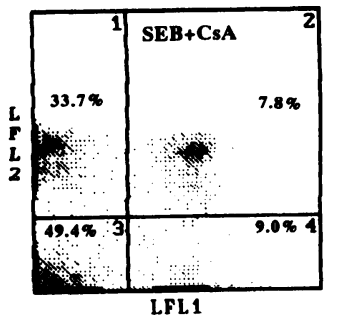

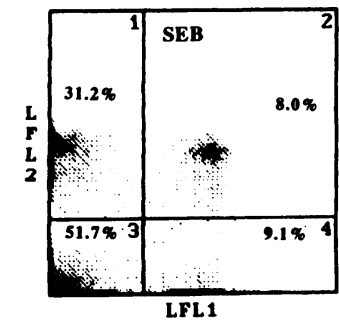

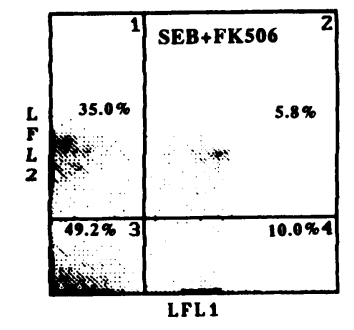

V及8
B
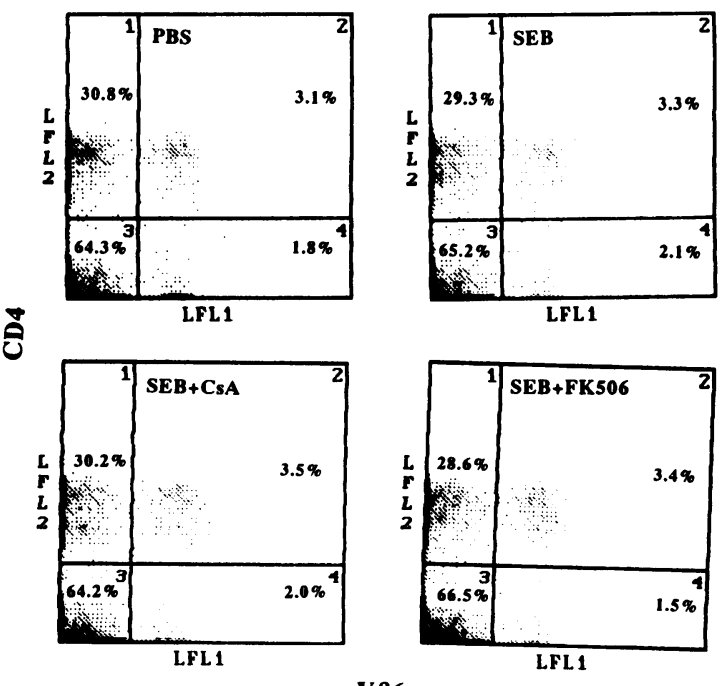

V及6

Figure 5. FK506 enhanced the reduction of $\mathrm{CD} 4{ }^{+} \mathrm{V} \beta 8^{+} \mathrm{T}$ cells induced by in vivo SEB administration. Balb/c mice were injected intraperitoneally with PBS or SEB $(50 \mu \mathrm{g})$. After $72 \mathrm{~h}$ of injection, mice were injected with CsA $(50 \mathrm{mg} / \mathrm{kg})$, FK506 $(2 \mathrm{mg} / \mathrm{kg})$, or PBS. On day 7 after the first injection, mice were killed, and spleen T cells were stained with anti-V $\beta 8$ (FITC, $A$ ) or anti-V $\beta 6(B)$ and anti-CD4 (PE) and analyzed by a flowcytometer. 
onstrated that FK506 and CsA block T cell activation by inhibiting $\mathrm{T}$ cell receptor-mediated transcription of IL-2 gene (57). After organ transplantation, the promotion of $T$ cell tolerance to alloantigen may be established by FK506, but the precise effect of FK506 on in vivo alloantigen-activated T cells is not well understood. It is possible that under the continuous presence of alloantigen chronically stimulated $T$ cells may be negatively regulated by FK506. Alternatively, allotolerance may be induced by the deletion of alloantigen-stimulated immunocomponents.

In our experiments, we investigated the effects of FK506 on apoptosis of antigen-stimulated thymocytes and peripheral $T$ cells. Our results demonstrated that DNA fragmentation of thymocytes, induced by anti-CD3 Ab stimulation, was augmented by in vivo FK506 treatment. Such a phenomenon was associated with a profound disappearance of $\mathrm{CD} 4{ }^{+} \mathrm{CD} 8{ }^{+}$thymocytes. To determine whether FK506 enhances apoptosis exclusively in antigen-stimulated $\mathrm{T}$ cells, we used a superantigen to induce thymic apoptosis. Taking advantage of the property of V $\beta 8$ specificity of SEB (24), we also examined the effect of FK506 on SEB-mediated thymic apoptosis. Our results confirmed that FK506 augments DNA fragmentation of antigenstimulated thymocytes exclusively, as made evident by the detection of a significant DNA ladder pattern observed in SEBreactive $\mathrm{V} \beta 8$-positive thymocytes but not in SEB-nonreactive $\mathrm{V} \beta 6$-positive thymocytes.

As well as thymocytes, mature $T$ cells are subject to clonal elimination as demonstrated in studies using different superantigens, such as the mouse mammary tumor virus-encoded antigen or bacterial superantigens $(10,11)$. We examined the effect of FK506 on in vivo SEB-activated spleen T cells. Our results demonstrated that in vivo FK506 treatment enhanced DNA fragmentation of SEB-activated spleen $T$ cells. The augmented DNA fragmentation resulted in a profound reduction of $\mathrm{CD} 4^{+}$ $\mathrm{V} \beta 8^{+}$population in SEB-FK506-treated mice.

Our results demonstrated that CsA partially blocked antiCD3-induced in vivo thymic apoptosis in agreement with a previous report (25). Although both drugs have indistinguishable effect by blocking the transcription of IL-2 gene, CsA and FK506 may have a differential effect on thymic apoptosis in vivo. For example, CsA is responsible for the induction of $\mathrm{T}$ cell-mediated autoimmunity under certain circumstances $(26$, 27 ). In contrast to the inhibitory effect on thymic apoptosis in vivo, repeated CsA injection increases the deletion of peripheral $T$ cells stimulated by SEB (28).

FK506 treatment improves immunosuppressive therapy for allograft rejection $(29,30)$. Tolerance to allograft, induced by FK506, may be attributed to the molecular action of FK506 by inhibiting the signal transduction of alloactivated $\mathrm{T}$ cells. Our results suggest an additional possible mechanism for the immunological tolerance established by FK506. FK506 may induce tolerance to allograft by provoking the elimination of alloantigen-activated $\mathrm{T}$ cells by apoptosis. In this regard, Bishop et al. (31) recently demonstrated that FK506 prevented the generation of alloantigen-induced cytolytic and helper $\mathrm{T}$ lymphocytes by limiting the dilution assay. GVHD is also a systemic manifestation of transplanted $\mathrm{T}$ lymphocyte activation in response to alloantigen (32). Furthermore, recent studies have demonstrated that FK506 treatment prolongs GVHD-free stage by removing alloantigen-stimulated donor $\mathrm{T}$ lymphocytes and that FK506 is superior to CsA in preventing GVHD stage $(33,34)$.
These reports support our hypothesis that alloantigen-stimulated $\mathrm{T}$ cells may be deleted by in vivo FK506 treatment.

In summary, our results indicate that in vivo FK506 treatment eliminates antigen-stimulated $\mathrm{T}$ cells by apoptosis. This FK506-mediated elimination of activated $T$ cells may represents a new mechanism of FK506-induced immunological tolerance to alloantigen.

\section{Acknowledgment}

This work was supported by Fujisawa Pharmaceuticals.

\section{References}

1. Kino, T., H. Hatanaka., M. Hashimoto, M. Nishiyama, T. Goto, M. Okuhara, M. Kohsaka, H. Aoki, and H. Imanaka. 1987. FK506, a novel immunosuppressant. isolated from a Streptomyces. I. Fermentation, isolation, and biological characteristics. J. Antibiot. (Tokyo). 40:1249-1255.

2. Kino, T., H. Hatanaka, S. Miyata, N. Inamura, M. Nishimura, T. Yajima, T. Goto, M. Okuhara, M. Kohsaka, and H. Imanaka. 1987. FK506, a novel immunosuppressant, isolated from a Streptomyces. II. Immunosuppressive effect of FK506 in vitro. J. Antibiot. (Tokyo). 40:1256-1265.

3. Thomson, A. W. 1990. FK506. Profile of an important new immunosuppressant. Transplant. Rev. 4:1-13.

4. Starzl, T. E., S. Todo, J. Fung, A. J. Demetris, R. Venkataramman, and A. Jain. 1989. FK506 for liver, kidney, and pancreas transplantation. Lancet. ii:10001004.

5. Tocci, M. J., D. A. Matkovich, D. Kwoek, F. Dumont, K. A. Collier, S. Lin, S. Degudicibus, J. J. Siekierka, J. Chin, and N. Hutchinson. 1989. The immunosuppressant FK506 selectively inhibits expression of early T cell activation gene. J. Immunol. 143:718-726.

6. Yoshimura, N., S. Matsui, T. Hamashima, and T. Oka. 1989. The effect of a new immunosuppressive agent, FK506, on human lymphocyte response in vitro. Inhibition of the production of IL-2 and $\gamma$-IFN, but not B cell-stimulating factor 2. Transplantation (Baltimore). 47:356-359.

7. O'Keefe, S. J., T. Tamura, R. L. Kincaid, M. J. Tocci, and E. A. O'Neill. 1992. FK-506 and CsA-sensitive activation of interleukin-2 promoter by calcineurin. Nature (Lond.). 356:692-694.

8. Kappler, J. W., N. Roehm, and P. Marrack. 1987. T cell tolerance by clonal elimination in the thymus. Cell. 49:273-280.

9. Fowlkes, B. J., R. H. Schwartz, and D. M. Pardoll. 1988. Deletion of selfreactive thymocytes occurs at $\mathrm{CD}^{+} \mathrm{CD}^{+}$precursor stage. Nature (Lond.). 334:620-623.

10. Kawabe, Y., and A. Ochi. 1991. Programmed cell death and extrathymic tolerance to Staphylococcus aureus enterotoxin B. Nature (Lond.). 349:245-247.

11. Webb, S., C. Morris, and J. Sprent. 1990. Clonal elimination as a consequence of immunity. Cell. 63:1249-1256.

12. Wyllie, A. H., J. F. R. Kerr, and A. R. Curriie. 1980. Cell death: the significance of apoptosis. Int. Rev. Cytol. 68:251-306.

13. MacDonald, H. R., and R. K. Lees. 1990. Programmed cell death of autoreactive thymocytes. Nature (Lond.). 343:642-644.

14. Smith, C. A., G. T. Williams, R. Kingstone, E. J. Jenkinson, and J. J. T. Owen. 1989. Antibodies to CD3/T-cell receptor complex induce death by apoptosis in immature T cells in thymic culture. Nature (Lond.). 339:181-184.

15. Uckun, F. M., L. Tuel-Ahlgren, C. W. Song, K. Waddick, D. E. Meyers, J. Kirihara, J. A. Ledbetter, and O. Schieven. 1992. Ionizing radiation stimulates unidentified tyrosine-specific protein kinases in human B-lymphocyte precursor, triggering apoptosis and clonogenic death. Proc. Natl. Acad. Sci. USA. 89:90059009.

16. Laster, S. N., J. G. Wood, and L. R. Gooding. 1988. Tumor necrosis factor can induce both apoptotic and necrotic form of cell lysis. J. Immunol. 141:26292634.

17. Weller, M., D. B. Constam, U. Malipiero, and A. Fontana. 1994. Transforming growth factor-beta 2 induces apoptosis of murine $T$ cell clones withou down-regulating bcl-2 mRNA expression. Eur. J. Immunol. 24:1293-1300.

18. Leo, O., M. Foo, D. H. Sacks, L. E. Samelson, and J. A. Bluestone. 1987. Identification of a monoclonal antibody specific for a murine T3 polypeptide. Proc. Natl. Acad. Sci. USA. 84:1374-1378.

19. Staerz, U. D., H.-G. Rammense, D. J. Benedetto, and J. M. Bevan. 1985. Characterization of a monoclonal antibody specific for an allotype determinan on T cell antigen receptor. J. Immunol. 134:3994-4000.

20. Perandones, C. E., V. A. Illera, D. Peckham, L. L. Stunz, and R. F. Ashman. 1993. Regulation of apoptosis in vitro in immature murine spleen $T$ cells. J. Immunol. 151:3521-3529. 
21. Shi, Y., R. P. Bissonnnette, N. Parfrey, M. Szalay, R. T. Kubo, and D. R Green. 1991. In vivo administration of monoclonal antibodies to the CD3 T cell receptor complex induces cell death (apoptosis) in immature thymocytes. $J$. Immunol. 146:3340-3346.

22. Lin, Y.-S., H.-Y. Lei, T. L. K. Low, C.-L. Shen., L.-J. Chou, and M.-S. Jan 1992. In vivo induction of apoptosis in immature thymocytes by staphylococcal enterotoxin B. J. Immunol. 149:1156-1163.

23. Kawabe, Y., and A. Ochi. 1990 . Selective anergy of $\mathrm{CD}^{+} \mathrm{V} \beta 8^{+} \mathrm{T}$ cells by staphylococcal enterotoxin B. J. Exp. Med. 172:1065-1070.

24. Janeway, C. A. 1991. Selective elements for $\mathrm{V} \beta$ region of the $\mathrm{T}$ cell receptor: Mls and bacterial toxin mitogen. Adv. Immunol. 50:1-53.

25. Shi, Y., B. M. Sahai, and D. R. Green. 1989. Cyclosporin A inhibits activation-induced cell death in T-cell hybridoma and thymocytes. Nature (Lond.). 339:625-626.

26. Prud'home, G. J., N. A. Parfrey, and L. E. Vanier. 1991. Cyclosporininduced autoimmunity and immune hyperreactivity. J. Autoimmun. 9:345-350.

27. Bucy, R. P., Y. Xu, J. Li, and G. Q. Huang. 1993. Cyclosporin A-induced autoimmunity disease in mice. J. Immunol. 151:1039-1050.

28. Vanier, L. E., and G. J. Prud'home. 1992. Cyclosporin A markedly enhances superantigen-induced peripheral $\mathrm{T}$ cell deletion and inhibits anergy induction. J. Exp. Med. 176:37-46.
29. Ochiai, T., K. Nakajima, N. Nagata, T. Hori, T. Asano, and K. Isono. 1987. Studies of induction and maintenance of long-term graft acceptance by treatment with FK506 in heterotopic cardiac allotransplantation in rats. Transplantation (Baltimore). 44:729-733.

30. Todo, S., Y. Ueda, J. A. Demetris, O. Imventarza, M. Nalesnik, R. Venkataramanan, L. Makowka, and T. E. Starzl. 1988. Immunosuppression of canine, monkey and baboon allograft by FK506 with special reference to synergism with other drugs and to tolerance induction. Surgery (St. Louis). 104:239-249.

31. Bishop, P. K., and W. Li. 1992. Cyclosporin A and FK506 mediate differential effects on T cell activation in vivo. J. Immunol. 148:1049-1054.

32. Korngold, R., and J. Sprent. 1987. T cell subsets and GVHD. Transplantation (Baltimore). 44:335-339.

33. Markus, P. M., X. Cai, W. Ming, A. J. Demetris, J. J. Fung, and T. E. Starzl. 1991. Prevention of graft-versus-host disease following allogeneic bone marrow transplantation in rats using FK506. Transplantation (Baltimore). 52:590-594.

34. Blazar, B. R., P. A. Taylor, W. E. Fitzsimmons, and D. A. Vallera. 1994. FK506 inhibits graft-versus-host disease and bone marrow graft rejection in murine recipients of MHC disparate donor grafts by interfering with mature peripheral T cell expansion post-transplantation. J. Immunol. 153:1836-1846. 